\title{
Cross Border Minority Issues in the Czech Republic, Poland and Slovakia: Challenges for Security in a Dynamic Environment
}

\author{
Sylwia Winiarska \\ National Defence University, Warsaw, Poland
}

\begin{abstract}
Czech Republic, Poland, and Slovakia's centuries long common history, their own attainments in the statehood conceptions among the Central European region, their commitment to the development of respective nations make their inter-state relations a unique political, economic, social, and cultural network. Their neighborhood, and the history of their relations relate to all kinds of ties on bilateral and trilateral levels - from close cooperation and friendship to distance, hostility, and even conflict. The peculiarity of their cooperation was highly influenced with 18th century partitions that directed and structured their nation safeguarding processes and political maturity. The division between Austro-Hungarian and Prussian empires mainly (as Poland was also under the Russian domination), impacted the Czech, Polish and Slovak citizenship and involvement into the activity of their countries rebuilt after World War I. The different models of rule consisting on politically adapted approaches to the national composition of the empires slightly diverged and thus the resulting status quo of the minority groups, and above all their attitude to the rule of their respective countries made up their heritage, memory, and identity respectively as Czechs, Poles, and Slovaks. To understand the issue of potential chances and challenges of the modern Czech-Polish-Slovak relations, this paper presents a historical overview of their relations. The second part of the paper stresses the main characteristics of the national identity of these three countries, to focus in the last part our attention on the question of the most probable challenges and potential threats to their cooperation.
\end{abstract}

Key words: national and ethnic minorities, national identity, inter-state relations, security environment, challenges and threats to security, nation building process

\section{The Historical Overview of the Czech-Polish-Slovak Relations: A Fluctuation in National Interests}

The area of Central Europe is relatively restrained while compared to the Western Europe, and inhabited by various ethnic, and national groups. Therefore it has always been disputed mainly for the reason of the resources scarcity, e.g. in water, arable lands, trade routes, but also sustainable settlement. The ethnocentric functioning of Central European groups of peoples is one of the consequences of those difficult environment purposes, but in the same time it is the cause of ethnic reluctance toward other groups ${ }^{1}$. This reluctance, issued from the uncertainty of the statehood, is the very essence of the interethnic relations in the region.

Because of its shortage, and instable borders of the regional states, land has never been the forefront of

Sylwia Winiarska, Ph.D., International Cooperation Center, National Defence University.

1 The literature gives numerous examples of that characteristic differentiating the Central European countries from the Western European ones, formed on the value of "national" land (Ersoy, Górny, \& Kechriotis, 2010; Cole, 2007; Krejči, 2005, p. 263). 
nationhood in the region, but affiliation to a given national or ethnic group ${ }^{2}$. Only this ethnic association, sense of community, involvement into a given group functioning was able to assure a sense of security, however volatile. Soon, as in the early 9th century, ethnic or national membership and identity built on that ground was reinforced by the Christian religion spreading to the Czech Kingdom, the Polish Kingdom, and to the Hungarian Kingdom. Later this Christian mission went further to Lithuania, Belarus, and partly to Ukraine ${ }^{3}$.

The early Middle Ages along Christianity permitted to form statehood based on hereditary rules, and strong hierarchic (vassal) rule that continued until the late 18th century. The issue of minority groups was put in the forefront of the national politics in different states in the region in the 16th century, when the strongest kingdoms united with different other lands. Among cited extensions might be the union between Poland and Lithuania (further extended to Bielarus, and Ukraine in the 17th century), Czech Kingdom and Slovakia, Silesia, and the Hungarian Kingdom encompassing a part of Transsilvania, today's Ukraine, and Moldova.

The greater the territory, the more numerous different ethnic groups, the more the rule would have to become decentralized to keep the balance of power and control over the given territories ${ }^{4}$. Poland had made the mistake to withdraw power over Ukraine to ethnic groups led by elite families of the country, what conducted to several uprisings and finally to the disrupt of the Ukrainian region at the very beginning of the 17th century. The same fate concerned Transsilvania in the Hungarian Kingdom, and Slovakia would also begin to search for its own path.

Between 13th to 17th centuries, one major threat appeared to be reluctant - the expansion of the Ottoman Empire to the Northern and Western Europe. The relations between Central European countries and the great neighbour from the Adriatic Sea were tumultuous, moving from tensed to cooperative, but most of all depended on economic conjuncture ${ }^{5}$. If trade insufficiently responded to Hungarian, Polish, Czech, and Ottoman interests, or the then economic exchange was insufficient, it led to violent conflict demanding a skilful cooperation among the Christian states. Of course, religion, precisely the resulting domination, and the safeguard of Christianity was among the key factors for war with Islam in the region ${ }^{6}$. Cooperation through marriages, but also political arrangements at that period was of crucial importance for the statehood, and social cohesion.

The 18th century meant a turning point in the statehood paradigms, the political power distribution, and civil rights development. The revolutionary ideologies, followed by great state, legal, military, and social reforms succeeded in the occidental part of Europe, but would last longer in the oriental part of the continent, what would inevitably bring neighbouring states to be interested over their lands, improperly ruled at the time. Incorporation to the extensive empires of the end of the 18th century meant the loss of territorial and political sovereignty for the Czech, Polish, and Slovak peoples. Thus becoming minorities in the newly established empires, those peoples felt strong needs to safeguard their integrity and cultural identity from the majority of

\footnotetext{
2 The ages long processes of borders regulations in the region still have strong impact on ethnic prejudice among today's nations in Central Europe. These prejudices are reluctant especially in border areas (Zick, Pettigrew, \& Wagner, 2008; Cordell \& Wolff, 2014).

3 The Christianism spread slowly into the regional states, and on its ground new norms, values, and rule systems were implemented (Biskup, 2005).

${ }^{4}$ As far as it concerns the case of Poland and Lithuania, a union of two nations was set up at Lublin (South-Western Polish city) in 1569. This federation consisted of two distinct governments, where the Polish King was the ruler, and the Lithuanian side was represented by the Great Duke of Lithuania (Koyama, 2014; Rodrigues, 2014).

5 The evolution of the relations between the Christian Europe and the Muslim Ottoman Empire depended not only on religious conflicts, but also resulted from trade competition between Europe and Asia.

${ }^{6}$ The continuity of Muslim and Christian rivalry lasted until late 17th century, when Polish King John the III Sobieski won the battle of Vienna on September 12th, 1683 retaining Ottoman troops heading the Western European countries.
} 
the nations they were incorporated to ${ }^{7}$, what soon would become a merging character for those peoples.

This need was not equally strong in all of the empires of that time. Depending on the type of rule, it followed different approaches, and evolution. As the Austrian, and since 1868, the Austro-Hungarian Empire were structured in a liberal internal, social policy $^{8}$, the minorities could provide their rule over a part of the national territory on the model of regional autonomy. In the contrary, the Hungarian, Prussian and Russian model diverged slightly from the mentioned Austrian one. Being much more restrictive, it consisted on magiarization, and Russification ${ }^{9}$, and high fiscal liabilities, and confiscations of property rights were means of dependence. Uprisings were a norm, all acts of violence were an effective catalyser of nation building processes that would take the shape of nations in the aftermath of the first world conflict.

In the years 1947-1989, Soviet totalitarianism imposed categorically re-Russification of the Central European region. Despite the dominance of the Soviet system, certain concessions were sometimes made. This process strongly expanded social depletion, and displacement of minority language from public life after the uprisings became a norm, than it was replaced by correspondence in the judiciary, church institutions in Russian (Ogonowski, 2000, pp. 13-16). Prussian annexation in 1870 under the Germanization just formed their nationality policy in terms of language, of which the lands inhabited by the Polish minority were treated with specific and consistent ruthlessness (Ogonowski, 2000, pp. 16-18). The Hungarian Kingdom followed the same model.

As part of the national strains equality under the Austrian rule gave the right to promote and develop the language of the parent (Landesprachen), in Galicia Polish language was the language of proceedings in the public sphere (Ogonowski, 2000, pp. 19-23). Although the liberalism, the language policy quickly became an instrument of discrimination not only social, but also economic, because without the knowledge of the invader, it was impossible to work, or even in official errands. As social changes accompanying political disturbances evolved, and new social order emerged, with the consequent development of civil rights along with progressive laicisation of states, ethnic and national redemptions revived.

The 20th century was characterized by huge and dramatic changes in the international legal system of conflict resolution. All consequent systems set up at multinational level with strong control of the 19th century powers led to further conflict escalation. The radicalisation of interethnic relations within nation states in the first two decades of the 20th century and interstate disputes, especially before the outbreak World War I was the primary cause of mass population movements (Eberhardt, 1996, p. 20). It should be emphasized that the escalation of conflicts between states on national and ethnic origin was so bright from the international community. Due to its strategic interests in the southern part of Central Europe and alliances dictated by

\footnotetext{
7 The lack of security ensured by the membership to a national majority ruling its own land comes from the very instinctive process of social contract - giving up of one's liberty, sovereignty in the return expecting security provision by an organized state. Becoming a member of a foreign state means a loss in the liberty, sovereignty, and confidence in the newly established regime.

${ }^{8}$ In the Austrian part of the Empire, the policy was relatively liberal towards the minorities, however, the same cannot be said about its Hungarian part, as the Slovak minority was subject of a restrictive policy called magnetization (forced linguistic, religious, heritage assimilation to the Hungarian people). The difference of the policies was allowed by the Constitution of the 1868 , as it granted relative independence to Hungarian government on the social, economic, and administrative issues on its territory.

${ }^{9}$ Germanisation, and Russification are terms used to describe policies of forced assimilation to the respectively Prussian and Russian rule over annexed territories. Both powers did not expect Czech, and Polish mainly disobedience and flaky, and started to use more, and more restrictive political instruments to pacify the violent tensions arising around the questions of language in the administration, and religious communion, language in education, labour market discrimination, and restrictions in internal migrations.
} 
economic considerations, the United Kingdom was the most influential force dictating solution to the ethnic and territorial.

According to Eric D. Weiz, the transition from the "Vienna system" in 1815 the "Versailles system" created in 1919, marked a turning point in international politics, as the essence of the peace treaties concluded there was only soft protection on territories, and also the nations and ethnic groups were still an object of policy, rather than a subject. Negotiations during the peace conference at Versailles and the content of the Lausanne has shown, furthermore, that forced population movements were an instrument to create a new regional order in Central Europe, and the issue of safeguarding the interests of minority groups was secondary (Troebst, 2012).

The Potsdam Treaty (August 2, 1945) contained the ongoing peace conference from July 17, 1945 between the most influent states in the aftermath of the second world conflict. It regulated the issues of demilitarization, densification, war reparations and forced resettlement of Germans from Eastern lands. The Polish border, drawn on the example of the Curzon line, was achieved in peculiar geopolitical conditions balancing between the Western and the Soviet interests (Eberhardt, 2012). It was a natural consequence of the conference in Tehran, where the Polish question and other countries in the region in the face of the growing influence of Soviet Russia was secondary to the UK and the USA, preferring stabilization in Africa, the Middle East, and Western Europe leaving Central European states in the influence area of the Union of Soviet Socialist Republics (USSR).

The transition period dating of 1989-1999, demonstrated the potential of cooperation to create social and political systems that would commit with western world values. Informal consultations succeeded in view to reform the political system and to put the human rights at the very center of attention of the newly established powers. Market liberalization, private property rights restitution followed soon after (Buiter, 2004). This difficult, demanding socially challenge proved that historical background could be of second importance compared with mutual interests coming from multilateral cooperation aimed at achieving mutual goals.

\section{Characteristics of The National Identity in the Czech Republic, Poland, and Slovakia}

Political dominance of France, Prussia and Great Britain, which vividly delineated at the beginning of the 19th century in international relations, and the simultaneous concentration of forces on the continent and relatively coincident economic cooperation transposed their balance of power directly on international social policy, mainly aimed at unprecedented ethnic engineering in diverse regions of Central Europe (Sundhaussen, 2014).

Two conferences under the leadership of the then economic powers - the Congress of Vienna (1814-1815) and the Berlin Conference (1884-1885) aimed at introducing a new international order and change the security concept great nations of Europe, moreover confirmed the Central European geopolitical division sanctioned by the end of the 18th century (Koskenniemi, 2007). Fierce rivalry between France and Britain for domination of international relationships revealed an even more increased strength after World War I, when deprived of their own state entities Central European nations used the post-war political vacuum to recover the lost sovereignty.

Central European area has become one of the most unstable regions of the continent in terms of inter-ethnic inter-nations relations. The history of interstate relations was closely linked with the issue of division within national boundaries among numerous and strongly culturally diverse national and ethnic groups. Throughout history and in their territorial divisions due to high volatility, the state borders drove to permanent and antagonistic conflicts over political, economic, cultural and social life. According to Simona Škarbec 
(2005), Central Europe as a concept is possible only if we agree with the assumptions considered the distributed nature of the event, appropriate only for it (p. 13). The many aspects of relations between the countries of the region, increasing the friction between nations and ethnic groups led to a unique mosaic of inter-ethnic and inter-nations on the continent.

The uniqueness of that mosaic is key to understand the social and cultural challenges in the region. Belonging to a particular ethnic group accompanied by high ethnocentricity, which for centuries have been confronted to wide attempts of assimilation, Central European forced most of the minorities to adaptation to majority groups, as well as more expansive national groups in the region, drives to strong self-identification (group identification) and opposes to other groups within the nation (Blair \& McCormack, 2009, pp. 21-35). Particularly noteworthy is the fact that the characteristic in the Central European region is this ethnocentrism that had an unsteady impact on the sense of common origin and common cultural traits, which include language, traditions, religion, as well as the social structure.

Piotr Madajczyk ${ }^{10}$ shows several stages of assimilation processes undertaken by national states aimed at the national and ethnic minorities at the turn of the century, which were countered consolidation and organized action of striking a vital national political interests: (1) political support "soft" integration towards assimilation also through schools and the military; (2) support the forced pursuing political goals in an ever broader spectrum; (3) then formally discriminatory and forcibly forcing them to leave; (4) this forced exchange of population on the basis of "free choice" nationality; (5) then the displacement of the population has not undergone pressure from the authorities and were forcibly relocated as a result of varying degrees of brutality activities of the authorities; and (6) in the final phase of the process we are dealing with deportation usually without compensation (Madajczyk, 2010, p. 13).

Transforming geopolitical order in Europe at the turn of the century led to social crises due to frequent involuntary resettlement and restrictive social and cultural policies towards minorities in the countries of Central Europe in the early 20th century (Orłowski, 2009). Multinational states in the region carried out their vital national interests in the form of political sovereignty and subordinated territorial integrity needs of national and ethnic minorities.

Viable security goals of nation-states created after the collapse of the central powers - maintaining the territorial and political balance between Prussia and Russia (by then Soviet) and preventing them from re-expansion-legitimized the emergence of nationalist tendencies. Geopolitical reshaping of new territorial units was in a way the symptom of political stabilization in the region ${ }^{11}$.

Ethnic governance in Central and Eastern Europe in the 20th century was a consequence not only of geopolitics established in the late 19th century, but first and foremost modernist approach to conflicts of ethnically-motivated ethnic and national and ethnic minorities in international relations in Europe. It did not change the trend shaping the security of the region by the Western powers, in which special role played the United Kingdom in the first two decades of the 20th century (Madajczyk, 2010, p. 12).

The evolution of issues concerning national minorities was further converted into social and political processes, more precisely the totalitarian regimes (Etzelmüller, 2012) and in the second half of the 20th century.

\footnotetext{
${ }^{10}$ Piotr Madajczyk, Polish Academy of Sciences, specialized in bilateral Polish-German relations in the historical, and social context.

11 Representatives of geopolitical schools in the 19th and 20th century in the Central Europe were: Viktor Dvorský (Czechoslovakia), Eugeniusz Romer (Poland), Simion Mehedenti (Romania), Stepan Rudnićky (Ukraine), János Hunfalvy (Hungary).
} 
Once again sweeping structural changes, the ethnic question called political transformation. Therefore, a holistic approach in terms of political plexus, geopolitical influence, international relations and social change processes in the 20th century have been the cause of many negative, destructive tendencies, which among them isolation and marginalization action against minority communities.

Strategic thinking of the then authorities based on the transformation of the Central European societies consisted on resettlement actions on the morrow of World War II (Etzelmüller, 2012, p. 253). The main motive and argument was to remove a potential threat to the security of the newly established states. The major victims of this instrumentalization was the German minority (Czechoslovakia, Poland, Hungary), the Ukrainian minority (Poland, Slovakia), and the Slovak minority (Hungary). Other national minorities in the traditional idea of the nationality of the Central European countries were treated with hostility and were covered by similar actions in similar way.

The democratization of countries liberated from the totalitarian system was designed to create a civil society that based on the principles of social equality and participation would create a new social system for minority groups predicted a new framework of operation, and legal and political freedom. The resulting empowerment of national and ethnic minorities in the last decade of the 20th century became one of the conditions for the further development of the region. One of the prerogatives was their accession to the various international institutions of a politico-economic (European Union, Council of Europe) and the politico-military (NATO) level.

The primary concern for the authorities of the transformation period was the legitimacy of power, as the key condition for its exercise (Sokól, 2000). It was known that the conviction of the rightness, properties and legitimacy was common, essential and sufficient condition is to produce an adequate cultural background and the effect of political culture, which would allow for the identification of many groups of national-ethnic with the new authorities.

It should be noted that international pressure of the 1990s in the 20th century (political pressure of the great powers over the years from 1900 to 1990 focused exclusively on the implementation of their national interests are often combined with prohibitively high social costs among the Central European nations) shaping a new social order, accompanied by centrifugal tendencies ${ }^{12}$ and ethnic diversification respect for the cultural rights of smaller groups of ethnic-national of historic significance for the individual Central European countries.

At the end of the 20th century, when the democratization of Central European states hastened along with the efforts of accession to the various regional and global organizations, the concept of education in developing multicultural conditions evolved in the direction of culturally diverse community. The social status, and wealth of the individual, the development of man towards the future with respect and appreciation for the past have created communities based on the paradigm of equality and a relative respect for diversity. That served to gradually remove accumulated prejudices, stereotypes, false ideas and fears of the co-inhabitants in different areas of the state.

\footnotetext{
12 The process of creating an international system of protection of the rights of national and ethnic minorities began 1945 years the adoption of the International Charter for the Protection of Human Rights, at which they were sanctioned further acts of politically binding international law (Janusz, 2011). In Central Europe, this process included not only the European Union but also on the Council of Europe and the CSCE / OSCE. The protection of the rights of minority groups was codified and standardized by the end of the $80 \mathrm{~s}$ of the twentieth century, the Central European countries which allowed a comprehensive and coherent reform towards empowerment of their national and ethnic minorities in the transition period.
} 


\section{Chances and Challenges to The Trilateral Cooperation in The Context of Minority Groups}

The aftermath of the World War I meant new border arrangements between newly established states ${ }^{13}$. As the national and ethnic minorities issues were latent in the Prussian and Russian annexations, and relatively well managed in the Austro-Hungarian Empire (another question was the Slovak minority under the Hungarian rule and its magiarization), it was obvious that territorial disputes would be inevitable. And so, along the Bolshevik War, 1919-1921, the first Russian political attempt to spread communism over Europe, but also the Ukrainian claims over Przemyśl and its surroundings followed quite stringent armed conflicts over the Tishyn (Czecho-Polish) $^{14}$ and Spisz (Polish-Slovak) ${ }^{15}$ territories.

However, before brief description of the euro-regions network acting among Czech Republic, Poland, and Slovakia, it is necessary to emphasize the reason for establishing them right after the erosion of the Soviet Empire. As mentioned in the second section of this paper, the economic condition of the border areas - dramatic unemployment rates, poor private sector activity, and overall low level of life-and above all conflicting social relations among neighboring nations marked by prejudice, and aversion for cooperation would cause intense barriers to the "European project" (Halás, 2007, p. 21). It was thus imperative to underpin those societies to openness, and relation building model of functioning.

The very first boost for sub-regional cooperation aimed at catalyzing the EU accession process was the Visegrad Group establishment ${ }^{16}$, an informal tripartite initiative involving the Czechoslovak Republic, Hungary, and Poland. Understanding the peculiarity of the situation at the beginning of the last decade of the 20th century - the instability of the security environment, the huge effort to make to reform the political, legal, social, economic systems of the countries - all three decided to unify their efforts to fasten, optimize, standardize the transformation process to join the Euroatlantic security community. The continuity of this difficult process of new kind of reterritorialization-restructuring of territorial forms of social relations organization (Popescu, 2008) — was to give a new impetus to border areas, and above all to diminish the barriers existing for centuries (strengthened by the communist period).

Nowadays, the Czech-Polish-Slovak border zone pertains to one of the most dynamic trans-border cooperation areas in Central Europe for which all three countries have developed respectively $13^{17}, 16^{18}$, and $16^{19}$ euro-regions since 1991. That constant growth in their number gives an idea about the significance of that tool within the neighborhood policy for economic, social, and cultural development in the sub-region. Created, activated, and converted on basis of international law $^{20}$, this mean has been used for a variety of local projects with strong involvement of local administrations, PME's, NGOs, and citizens for mutual welfare.

\footnotetext{
13 The political conditions, encompassing International arrangements, and legal systems, were extremely fragile and did not securise any of the then functioning border configurations. The Versailles System worked out for over five years with a couple of arrangements, did not respond to interests of different parties (states) in the region.

14 Retrieved from November 10, 2014, from http://www.dziennikzachodni.pl/artykul/1020353, spor-o-zaolzie-czylijak-czesi-ograli-polakow-w-1919-roku-historia-dz,id,t.html

${ }_{15}$ Retrieved November 10, 2014, from http://www.polskieradio.pl/39/284/Artykul/503035,Trudna-historia-Zaolzia

16 Retrieved November 10, 2014, from http://www.visegradgroup.eu/documents/visegrad-declarations/visegrad-declaration $-110412$

17 Retrieved November 18, 2014, from http://www.cesci-net.eu/euroregions-CZ

18 Retrieved November 18, 2014, from http://www.cesci-net.eu/euroregions-PL

19 Retrieved November 18, 2014, from http://www.cesci-net.eu/euroregions-SK. Most of the Slovak euro-regions are focused on cooperation with Hungary due to historical heritage (economic relations), and differences on Hungarian minority issues in Southern Slovakia.

${ }^{20}$ European Outline Convention on Trans-frontier Cooperation between Territorial Communities and Authorities (Madrid, May 21st, 1980), European Charter of Local Self-government (Strasbourg, October 15th, 1985).
} 
The remaining questions of restitutions of lands dating from 1958 between the Czech Republic and Poland, and Slovakia and Poland have also been discussed through the euro-regional cooperation, combining the governmental and the local level. The irregular situation of borders with the Czech Republic comes from an agreement signed between respective communist governments, stipulating an exchange of territories as: the communist Czechoslovakia received 1,200 hectares from the People's Republic of Poland, receiving in return only 840 ha. A territorial debt since then remained unchanged until the collapse of the Soviet Union. In order to control this problem, the Permanent Polish-Czech Border Commission at the Ministry of Internal Affairs in Warsaw $^{21}$ was set up in 1992.

The case of territorial adjustments between Poland and Slovakia are totally different, and concern more functional changes, then political debate issues. The "mechanical" problem was dictated by the changes that have occurred in the topography of the border ${ }^{22}$, and the two countries exchanged within the same surfaces, from 300 to 2,000 square feet. The agreement was signed in 2002 in the Lubowla, and entered into force in 2005. There have been three adjustments, changed the boundary extend along two roads so as not to be cut across the border and their status does not cause any problems in accessing the plots located next to them. Also changed the territory due to the inability of properly adjust the boundary markers.

Table 1

Distribution by Name of Czech Republic, Poland and Slovakia Border Regions

\begin{tabular}{|l|l|l|l|}
\hline & Czech Republic (Kraj) & Poland (Voivodship) & Slovakia (Kraj) \\
\hline \multirow{4}{*}{$\begin{array}{l}\text { Geographic location } \\
\text { of the national border }\end{array}$} & North-Eastern & South-Western & North \\
\hline & Liberecki, Ustrecki & Dolnośląskie & - \\
\cline { 2 - 4 } & Pardubicki, Hradecki & Opole & - \\
\cline { 2 - 4 } & Moravsko-Silesian, Olomuniecki, Pardubicki & Śląsk & Trencin \\
\hline $\begin{array}{l}\text { Geographic location } \\
\text { of the national border }\end{array}$ & & South-Eastern & \\
\hline & - & Matopolska & $\begin{array}{l}\text { Šaris, Spiš, Liptov, Orava, } \\
\text { Trencin }\end{array}$ \\
\cline { 2 - 4 } & - & Podkarpackie & Šaris, Zemplin \\
\hline
\end{tabular}

Note. The author's work based on administrative maps of respective countries.

As the Table 1 shows, the historical relations testify of conflictual four Czech-Polish-Slovak regions. Until today, no armed conflicts are expected anymore, as the time factor has already shaped identity among peoples inhabiting the mentioned regions, however national memory, or better named prejudice, concerning those conflicts still persist. The Versailles System established successively in 1919, distributed territories upon unfunded judgements, so the pretension, and claims are still a basis of negotiation between Polish and Czech governments. In 2011, a preliminary understanding ${ }^{23}$ has been signed, which represents a huge step forward to end the territorial disputes lasting nearly a century.

Since 1992 however, permanent intergovernmental commissions Polish-Czech, and Polis-Slovak

${ }^{21}$ Retrieved November 22, 2014, from http://www.stosunkimiedzynarodowe.pl/uregulowania-terytorialne-polski-z-s\%C 4\%85siadami-po-1989-r

${ }^{22}$ Retrieved November 22, 2014, from http://www.stosunkimiedzynarodowe.pl/uregulowania-terytorialne-polski-z-s\%C4 $\% 85$ siadami-po-1989-r

${ }^{23}$ The Polish and the Czech government did agree on the area of the disputed territories since 1923 (bilateral agreement...), that is to be followed by marginal border shifts instead of financial reimbursements negotiated by the Czech side right after the collapse of the Soviet system in the Central Europe. 
concerning the question of borders work on different issues concerning the border cooperation, such as bilateral trade, economy, transport, labor migration, life insurance in trans-border regions, crisis management ${ }^{24}$. In subsequent documents dating from 2011, 2012, and 2013 only, it is clear that cooperation on local administration level is promising, and effective solving current and strategic problems concerning communities on both sides of the borders. Political questions of border shapes are of second importance to the populations. The factor that in recent years boosted this bilateral cooperation between Poland and its two southern neighbors was the creation of euro-regions, supported with substantial funds for energy network, labor market transition, and education purposes.

Strategic issues of roads, and railways development and transport activation among the three countries are being worked out, so as to permit free, and responding to the real demand flux of persons and goods. Cooperation in the field of rescue in crisis occurrences ${ }^{25}$ consisting of exchange of information, procedure standardization, common action planning, common exercises develop quite efficiently. These examples show progressive development in common interests among the three partners on bilateral level.

\section{Conclusion}

The clash of national interests differences, the inequality in the economic and political potential, also the unbalanced social potential has conducted Czech, Polish, and Slovak relations to unstable and dichotomist coping through the ages. The Austrian liberal rule and its multinational statehood shaped a relatively developed and active social, political, and economic commitment of those three nations into the then state. Through elite building, the rise of nations was a catalyser to new state creation after World War I, what would become the first step of a long path for making the national and ethnic minorities a subject of international human rights system which was implemented in the 1990s only.

The impact of the soviet imperialism and its Homo Sovieticus ideology froze pendent conflicts, but with the beginning of the transformation process re-emerged. The security environment, and actually the insecurity or security gap, with current German and Russian expansionism, recurrent border shaping along the 20th century did very much impact the territoriality issue in the Central European region. Successes of the Conference for Security and Cooperation in Europe, peace building processes and human rights endowment made national and ethnic securitization slowly a key factor for cooperation. It concerned especially all former Soviet countries, as the Czech Republic, Poland, and Slovakia, because of their ambitions to join the West European community.

The turn of the 20th and 21st centuries, and upcoming slight and dynamic changes in the sub-regional, regional, and global security environment invited the three countries to find a common platform for achieving approximate national interests. Among those interests would be clue the question of mutually fruitful managing the border minorities. Although still latent territorial negotiations, today's cooperation in the frame of minority management seems to have succeeded though difficult past and experiences. Economic fluctuations, and above all economic crises have not negatively impacted relations between different minorities and the three states.

The challenge to come, however is the growing international migration, spreading military conflict on the

\footnotetext{
${ }^{24}$ Protocols from meetings of Polish-Czech, and Polish Slovak Intergovernmental Comissions on Trans-border Cooperation from 2013, 2012, 2011. Retrieved from file://C:/Users/Admin/Downloads/Protokol_z_XIX_posiedzenia_Polsko_Czeskiej_Komisji _Miedzyrzadowej_ds__Wspolpracy_Transgranicznej\%20(1).pdf

${ }_{25}$ Retrieved November 21, 2014, from https://msw.gov.pl/pl/aktualnosci/11545,O-wspolpracy-polsko-slowackiej.html
} 
Eastern Ukrainian border, that might infiltrate the neighboring countries, namely Poland and Slovakia. Still numerous Ruthenian and Ukrainian minorities might soon enlarge with sudden mass inflows. On the other side, steadily, but surely developing immigration from the Central Asia may also in the near future complicate the problem of minority management for Central European states that are still economically fragile, and thus have limited capabilities of migration absorption.

\section{References}

Blair, J. G., \& McCormack, M. (Eds.). (2009). Mapping ethnocentrism beginning comparative studies where comparisons start. Shanghai: Fudan University Press.

Biskup, M. (2005). Polish diplomacy during the Angevin and Jagiellonian Era (1370-1572). In J. S. Kugler \& K. Strembowicz (Eds.), The history of Polish Diplomacy 10th-20th Century (pp. 70-90). Warsaw: Sejm Publishing Office.

Buiter, W. H. (2004). What have we learnt from fifteen years of transition in Central and Eastern Europe? Paper prepared for the International Policy Conference on Transition Economies, 31 May and 1 June 2004, Hanoi, Vietnam. Retrieved from http://willembuiter.com/vietnam.pdf

Cole, L. (Ed.). (2007). Different paths to the nation: Regional and national identities in Central Europe and Italy, 1830-1870. Houndsmills: Palgrave Macmillan.

Cordell, K., \& Wolff, S. (Eds.). (2014). Ethnic Germans in Poland and the Czech Republic: A comparative evaluation. Retrieved November 11, 2014, from http://www.stefanwolff.com/files/EthnicGermansPolandandCzechRepublic.pdf

Eberhardt, P. (1996). Między Rosja a Niemcami. Przemiany narodowościowe w Europie Środkowo-Wschodniej w XX wieku. Warszawa: PWN.

Eberhardt, P. (2012). The Curzon line as the eastern boundary of Poland: The origins and political background. Geographia Polonica, 85(1), 5-21.

Ersoy, A., Górny, M., \& Kechriotis, V. (Eds.). (2010). Discourses of collective identity in Central and Southeast Europe 1770-1945, 3(1). Central European University Press.

Etzelmüller, T. (2012). Inżynieria społeczna i wymyślenie "kwestii ludnościowej”. In P. Madajczyk \& P. Popieliński (Eds.), Inżynieria społeczna. Między totalitarnq utopiq a czqstkowym pragmatyzmem (pp. 38-42). Warsaw: ISP PAN.

European Charter of Local Self-government (Strasbourg, October 15th, 1985).

European Outline Convention on Transfrontier Cooperation between Territorial Communities and Authorities (May 21, 1980). Madrid.

Halás M. (2007). Development of cross-border cooperation and creation of Euro-regions in the Slovak Republic. Moravian Geographical Reports, 15(1), 21-31.

Janusz, G. (Ed.). (2011). Protection of the rights of national minorities in Europe. Lublin: UMCS.

Koskenniemi, M. (2007). The legacy of the 19th century. Retrieved from http://www.helsinki.fi/eci/Publications/Koskenniemi/ MKLEGACY\%20OF\%20THE\%2019TH\%20CENTURY-07e.pdf

Koyama, S. (2014). The Polish-Lithuanian Commonwealth as a political space: Its unity and complexity. Retrieved November 9 , 2014, from https://src-h.slav.hokudai.ac.jp/coe21/publish/no15_ses/08_koyama.pdf

Krejči, O. (2005). Geopolitics of the Central European Region. The view from Prague and Bratislava. Veda: Bratislava.

Kugler, J. S., \& Strembowicz, K. (Eds.). (2005). The history of Polish diplomacy 10th-20th century. Warsaw: Sejm Publishing Office.

Madajczyk, P. (2010). Czystki etniczne i klasowe w Europie w XX wieku. Szkice do problemu. Warszawa: ISP PAN.

Ogonowski, J. (2000). Uprawnienia językowe mniejszości narodowych w Rzeczypospolitej Polskiej 1918-1939 (Language rights of national minorities in the Republic of Poland, 1918-1939). Warszawa: Wydawnictwo Sejmowe.

Orłowski, H. (2009). Stereotypy długiego trwania a procesy "nation building". In R. Traba (Ed.), Akulturacja/asymilacja na pograniczach kulturowych Europy Środkowo-Wschodniej w XIX i XX wieku. Stereotypy i pamięć, Vol. 1 (p. 25). Warszawa: ISP PAN.

Popescu, G. (2008). The conflicting logics of cross-border reterritorialization. Geopolitics of euro-regions in Eastern Europe. Political Geography, 27, 419-420.

Rodrigues, D. (2014). The Polish-Lithuanian peculiar type of federalism. Retrieved November 9, 2014, from http://vddb.library.lt/fedora/get/LT-eLABa-0001:J.04 2010 ISSN_2029-2074.N_5.PG_121-130/DS.002.1.01.ARTIC 
Skarbec, S. (2005). Imagined geography. The Conception of the Central Europe in the 20th Century.

Sokół, W. (2000). Dylematy legitymizacji w okresie zmiany systemowej. In J. A. Rybczyńska (Eds.), Europa Środkowo-Wschodnia. Region, państwa i społeczeństwa w czasie transformacji, Wyd (pp. 31-33). Lublin: UMCS.

Sundhaussen, H. (2010). Forced ethnic migration. European history online. Retrieved from file://C:/Users/Admin/Downloads/sundhaussenh-2010-en.pdf

Troebst, P. (2012). Od transferów ludności do zakazu wypędzeń-europejska historia sukcesu? In H. P. Müller \& M. Zielińska (Eds.), Transgraniczność w perspektywie socjologicznej (p. 41). Migracje przymusowe w Europie, Lubuskie Towarzystwo Naukowe, Zielona Góra.

Zick, A., Pettigrew, T. F., \& Wagner, U. (Eds.). (2008). Ethnic prejudice and discrimination in Europe. Journal of Social Issues, 64(2), 233-251 